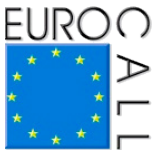

\title{
A pre-mobility eTandem project for incoming international students at the University of Padua
}

\author{
Lisa Griggio $^{1}$ and Edit Rózsavölgyi ${ }^{2}$
}

\begin{abstract}
This study focuses on a strategic partnership with students from the University of Padua and international students coming to Padua mainly in the setting of Erasmus student mobility and exchange programs. The project is designed specifically for incoming international students to facilitate their integration into the Italian higher educational learning environment. They can practice their Italian, have practical information about Padua and its university, and get to know local students with whom they can possibly have face-to-face relationships after their arrival. The online exchange - based on the principles of tandem learning - is carried out in the setting of a one-to-one and a many-to-many interaction using different technological tools which include a dedicated institutional Moodle platform, a social Facebook area restricted to the eTandem community and other networking systems such as Skype, e-mail, chat and WhatsApp. We have found that the project helps both Italian and international students develop their digital, linguistic and intercultural competencies, boosts their critical thinking and cultivates their curiosity towards others. It facilitates international students' integration into their target country/ university/culture.
\end{abstract}

Keywords: eTandem, pre-mobility, university students, international setting.

\section{Introduction}

New learning policies promote plurilingualism, internationalization, learner autonomy for lifelong learning and require the aptitude of young people to deal competently with the demands of linguistic and cultural diversity. To this aim, we have to rethink traditional notions and priorities of language education.

1. University of Padua, Padua, Italy; lisa.griggio@unipd.it

2. University of Padua, Padua, Italy; edit.r@unipd.it

How to cite this article: Griggio, L., \& Rózsavölgyi, E. (2016). A pre-mobility eTandem project for incoming international students at the University of Padua. In S. Papadima-Sophocleous, L. Bradley \& S. Thouësny (Eds), CALL communities and culture - short papers from EUROCALL 2016 (pp. 167-171). Research-publishing.net. https://doi.org/10.14705/rpnet.2016. eurocall2016.556 
Numerous educators and researchers have noted that the use of information and communication technologies in L2 teaching/acquisition seems to be the best way to cope with the challenge of internationally changing educational scenarios force upon us (e.g. Pareja-Lora, Rodríguez-Arancón, \& Calle-Martínez, 2016).

It has always been an uncontroversial assumption that one of the most effective ways of improving L2 communication skills is through enabling students to engage directly with native speakers. The potential of tandem interaction in online environments is self-evident. But technology itself is only a means to an end, and the actual application of Web 2.0 tools to exploit distant peer-to-peer activities for educational purposes is far from being simple and easy. Attractive and effective foreign language learning calls for an organized and structured framework which can give students the support they need in order to make the most of the opportunities that the wide variety of communicative channels they have at hand presents.

In this study we want to exchange good practices by providing the outcomes of an eTandem project carried out at the Padua University Language Center during the winter of the 2015-2016 academic year. The project welcomed Italian students from Padua University and international students that in the framework of student mobility programs such as Erasmus were coming to Padua for the spring term of the same academic year.

Our approach was plurilingual, intercultural, inclusive and attentive to the basic e-skills which 21 st century students need, i.e. strategies for effective online activities, ability to evaluate and use online sources of information, ability to use Internet applications for effective cooperation and collaboration (Dede, 2009; Fullan, 2013; Griffin, McGaw, \& Care, 2012; Klimczak-Pawlak, 2014). The objectives of the project were as such manifold:

- deepening students' linguistic competence via content-related input;

- promoting their ability to perceive and mediate the relationships which exist among languages and cultures;

- supporting respect for the plurilingualism of others and the value of languages and varieties irrespective of their perceived social status;

- upholding respect for the cultures embodied in languages and the cultural identities of others. 
Through the participation in this international cooperation project we wanted all students to enjoy multilingualism and not be afraid of it. Following the European educational priorities, key competences for lifelong learning (Europa, 2006) were in the forefront for better learning outcomes. By establishing a community-based learning via Facebook and by interacting and negotiating with their eTandem partners when it came to one-to-one interaction, students were engaged in meaningful communicative activities relevant to real life situations and it turned out to be creative as well as interesting for them.

\section{Description of the project}

In the pre-mobility eTandem project, 78 Erasmus students and 51 Italians enrolled. Because of the different number of participants between the two groups, not only dyads but some triads were formed as well. The project took place prior to the arrival of international students to Padua and lasted eight to ten weeks. It worked as a preparatory activity to their departure, boosting both their linguistic competence and a better insight into the culture of the host country and supported personal motivation for their Erasmus program.

As most online exchanges, our project aimed to promote autonomy and reciprocity (Vassallo \& Telles, 2006) in a real life language context through communication with native speakers of the target language and aspired to stimulate a deeper understanding of students' own as well as their peers' culture. Yet, our exchange offered the participants a double line of interaction: a one-to-one and a many-tomany communication mode. Besides the individual tandem in the target language with their partners, students could join our eTandem community in Facebook where different intercultural topics, either in Italian or in English used as lingua franca, were discussed. This social area implied an exchange on a wider basis: not only did it serve to put all participants in touch so that they could experience an enriching multilingual and multicultural context, but it also prevented students from dropping the exchange by creating group cohesion.

In the first week, students entered two different platforms, Moodle and Facebook. In the institutional Moodle area one was able to learn how to move the first steps in the eTandem setting and to browse some resources to support one's linguistic, digital and cultural knowledge. The project also included some theme-based asynchronous activities in Facebook on a weekly basis. Tutors proposed and moderated debates on both neutral/safe topics, like reading, traditions, food, etc., and controversial issues such as animal experimentation, legalization of soft drugs, promoting critical 
thinking, critical literacies and reflexivity. Any argument introduced in the social community environment could be dealt with in the individual interaction setting.

After each discussion, students were encouraged to write a diary. This type of activity served as a tool to reflect on and evaluate thoughts, ideas, feelings and students' own learning process closely following and recording their progress. The 'writing space' contributed to a growing self-awareness of students in their role of learners, but also helped tutors to have their fingers on the pulse of opinions and feelings of the eTandem community permitting a continuous adjustment of the project to students' needs, competences and suggestions.

\section{Analysis of the outcomes and conclusion}

Our analysis is based on two sources: (1) feedback questionnaire outcomes and (2) the observation of the 129 participants' activity in Facebook and in Moodle. At the end of the project students were asked to fill in a feedback questionnaire in order to reflect on their linguistic, digital and social learning outcomes. Out of 129 participants, only 22 responded.

The online questionnaire was composed of 28 items and students accessed it from the eTandem Moodle platform. The great majority of the questions was closed but in some cases students were given the opportunity to express themselves freely. We wanted to know about students' eTandem management and we were curious to know if they devoted any time to corrections and if so how they delivered it. The second part of the questionnaire dealt with students' opinion about the project and students' assessment. We asked if they think their own and their partner's knowledge of language improved or was useful for them and in which areas, if they got on well with their partner(s), and if they found it useful to write diaries. Further, we investigated the topics we proposed in the e-community and which topic(s) they preferred, if they used the language resources provided in Moodle, if they would have preferred more assistance and more structured activities, if they were going to keep in touch with their partner(s) once in Padova and if after this experience they felt more confident about going abroad in the setting of a student mobility. We also asked for a global assessment of students' eTandem experience and for any suggestions to give us in order to improve the project.

Data analysis indicates that the majority of students (72\%) found Facebook to be the most useful tool for interacting and used WhatsApp and e-mail equally (45\%). Skype was employed by few people $(36 \%)$ because of different time zones. 
It emerged that all but two people considered the project very or quite useful. 21 participants declared to be willing to stay in contact with their eTandem partner once he/she is in Padua and 17 Italian students stated to be more convinced to apply for an Erasmus scholarship after this experience.

The project brought benefits to the participants. Technologically speaking, students learnt how to use Moodle and Facebook, how to search and retrieve information from the web, how to use the net and social networks in a more responsible way defending their web reputation. Linguistically, they developed informal lexicon and written and oral skills both in English/Italian used as lingua franca and their target language. Participants became more competent in social skills such as commenting, sharing and interacting online, but also active listening, understanding diversity and respect for differences. All students reflected on and learnt about their own as well as other's culture while international students felt more integrated in the host campus.

\section{References}

Dede, C. (2009). Comparing frameworks for 21st century skills. http://watertown.k12.ma.us/ dept/ed_tech/research/pdf/ChrisDede.pdf

Europa. (2006). Recommendation 2006/962/EC of the European Parliament and of the Council of 18 December 2006 on key competences for lifelong learning. http://europa.eu/legislation summaries/education_training_youth/lifelong_learning/c11090_en.htm

Fullan, M. (2013). Stratosphere: integrating technology, pedagogy, and change knowledge. Toronto: Pearson.

Griffin, P., McGaw, B., \& Care, E. (2012). Assessment and teaching of 21st century skills. Dordrecht: Springer. https://doi.org/10.1007/978-94-007-2324-5

Klimczak-Pawlak, A. (2014). Towards the pragmatic core of English for European communication: the speech act of apologising in selected Euro-Englishes. Springer.

Pareja-Lora, A., Rodríguez-Arancón, P., \& Calle-Martínez, C. (2016). Applying information and communication technologies to language teaching and research: an overview. In A. ParejaLora, C. Calle-Martínez, \& P. Rodríguez-Arancón (Eds), New perspectives on teaching and working with languages in the digital era (pp. 1-22). Dublin: Research-publishing.net. https://doi.org/10.14705/rpnet.2016.tislid2014.418

Vassallo, M. L., \& Telles, J. A. (2006). Foreign language learning in-tandem: theoretical principles and research perspective. The ESPecialist, 25(1), 1-37. 


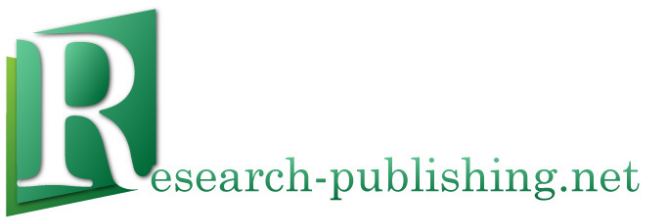

Published by Research-publishing.net, not-for-profit association Dublin, Ireland; Voillans, France, info@research-publishing.net

(C) 2016 by Editors (collective work)

(C) 2016 by Authors (individual work)

\section{CALL communities and culture - short papers from EUROCALL 2016 Edited by Salomi Papadima-Sophocleous, Linda Bradley, and Sylvie Thouësny}

Rights: All articles in this collection are published under the Attribution-NonCommercial -NoDerivatives 4.0 International (CC BY-NC-ND 4.0) licence. Under this licence, the contents are freely available online as PDF files (https://doi. org/10.14705/rpnet.2016.EUROCALL2016.9781908416445) for anybody to read, download, copy, and redistribute provided that the author(s), editorial team, and publisher are properly cited. Commercial use and derivative works are, however, not permitted.

\section{(9) $\Theta \Theta$}

Disclaimer: Research-publishing.net does not take any responsibility for the content of the pages written by the authors of this book. The authors have recognised that the work described was not published before, or that it is not under consideration for publication elsewhere. While the information in this book are believed to be true and accurate on the date of its going to press, neither the editorial team, nor the publisher can accept any legal responsibility for any errors or omissions that may be made. The publisher makes no warranty, expressed or implied, with respect to the material contained herein. While Research-publishing.net is committed to publishing works of integrity, the words are the authors' alone.

Trademark notice: product or corporate names may be trademarks or registered trademarks, and are used only for identification and explanation without intent to infringe.

Copyrighted material: every effort has been made by the editorial team to trace copyright holders and to obtain their permission for the use of copyrighted material in this book. In the event of errors or omissions, please notify the publisher of any corrections that will need to be incorporated in future editions of this book.

Typeset by Research-publishing.net

Cover design by (C) Easy Conferences, info@easyconferences.eu,www.easyconferences.eu

Cover layout by (c) Raphaël Savina (raphael@savina.net)

Photo "bridge" on cover by (C) Andriy Markov/Shutterstock

Photo "frog" on cover by (C) Fany Savina (fany.savina@gmail.com)

Fonts used are licensed under a SIL Open Font License

ISBN13: 978-1-908416-43-8 (Paperback - Print on demand, black and white)

Print on demand technology is a high-quality, innovative and ecological printing method; with which the book is never 'out of stock' or 'out of print'.

ISBN13: 978-1-908416-44-5 (Ebook, PDF, colour)

ISBN13: 978-1-908416-45-2 (Ebook, EPUB, colour)

Legal deposit, Ireland: The National Library of Ireland, The Library of Trinity College, The Library of the University of Limerick, The Library of Dublin City University, The Library of NUI Cork, The Library of NUI Maynooth, The Library of University College Dublin, The Library of NUI Galway.

Legal deposit, United Kingdom: The British Library.

British Library Cataloguing-in-Publication Data.

A cataloguing record for this book is available from the British Library.

Legal deposit, France: Bibliothèque Nationale de France - Dépôt légal: décembre 2016. 